\title{
Correction to: Assessment of a massive open online course (MOOC) incorporating interactive simulation videos on residents' knowledge retention regarding mechanical ventilation
}

\author{
Tai Pham ${ }^{1,2^{*}}$, Francois Beloncle ${ }^{3}$, Lise Piquilloud ${ }^{4}$, Stephan Ehrmann ${ }^{5}$, Damien Roux ${ }^{6,7}$, \\ Armand Mekontso-Dessap ${ }^{8,9,10}$ and Guillaume Carteaux ${ }^{8,9,10}$
}

\section{Correction to: BMC Medical Education (2021) 21:595 \\ https://doi.org/10.1186/s12909-021-03025-8}

Following publication of the original article [1], we have been informed that the authors Damien Roux, Armand Mekontso-Dessap and Guillaume Carteaux were incorrectly affiliated.

Also, the author Armand Mekontso-Dessap was incorrectly tag. We have tagged his name as follows:

First Name: Armand

Last Name: Mekontso-Dessap

The author group has been updated above and the original article [1] has been corrected.

\section{Author details}

'Service de Médecine Intensive-Réanimation, AP-HP, Hôpital de Bicêtre, DMU 4 CORREVE Maladies du Cour et des Vaisseaux, FHU Sepsis, Groupe de Recherche Clinique CARMAS, Le Kremlin-Bicêtre, France. ${ }^{2}$ Université Paris-Saclay, UVSQ, Univ. Paris-Sud, Inserm U1018, Equipe d'Epidémiologie respiratoire intégrative, CESP, 94807 Villejuif, France. ${ }^{3}$ Département de Médecine Intensive - Réanimation et Médecine Hyperbare, CHU d'Angers, Vent'Lab, Université d'Angers, Angers, France. ${ }^{4}$ Adult Intensive Care Unit, University Hospital and University of Lausanne, Lausanne, Switzerland. ${ }^{5}$ Médecine Intensive Réanimation, Inserm CIC 1415, Réseau CRICS-TRIGGERSEP F-CRIN network, CHRU de Tours and INSERM, Centre d'Etude des Pathologies Respiratoires (CEPR)
UMR 1100, Université de Tours, Tours, France. ${ }^{6}$ AP-HP, Hôpital Louis Mourier, DMU ESPRIT, Médecine Intensive-Réanimation, F-92700 Colombes, France. ${ }^{7}$ Université de Paris, UMR1137 IAME, INSERM, F-75018 Paris, France. ${ }^{8}$ Assistance Publique-Hôpitaux de Paris, CHU Henri Mondor, Service de Médecine Intensive Réanimation, F-94010 Créteil, France. ${ }^{9}$ Université Paris Est-Créteil, Faculté de Santé, Groupe de Recherche Clinique CARMAS, F-94010 Créteil, France. ${ }^{10}$ INSERM U955, Institut Mondor de Recherche Biomédicale, F-94010 Créteil, France.

Published online: 25 January 2022

\section{Reference}

1. Pham T, et al. Assessment of a massive open online course (MOOC) incorporating interactive simulation videos on residents' knowledge retention regarding mechanical ventilation. BMC Med Educ. 2021:21:595. https:// doi.org/10.1186/s12909-021-03025-8.

The original article can be found online at https://doi.org/10.1186/s12909021-03025-8.

${ }^{*}$ Correspondence: tai.pham@aphp fr

${ }^{2}$ Université Paris-Saclay, UVSQ, Univ. Paris-Sud, Inserm U1018, Equipe

d'Epidémiologie respiratoire intégrative, CESP, 94807 Villejuif, France

Full list of author information is available at the end of the article

(c) The Author(s) 2022. Open Access This article is licensed under a Creative Commons Attribution 4.0 International License, which permits use, sharing, adaptation, distribution and reproduction in any medium or format, as long as you give appropriate credit to the original author(s) and the source, provide a link to the Creative Commons licence, and indicate if changes were made. The images or other third party material in this article are included in the article's Creative Commons licence, unless indicated otherwise in a credit line to the material. If material is not included in the article's Creative Commons licence and your intended use is not permitted by statutory regulation or exceeds the permitted use, you will need to obtain permission directly from the copyright holder. To view a copy of this licence, visit http://creativecommons.org/licenses/by/4.0/. The Creative Commons Public Domain Dedication waiver (http://creativeco mmons.org/publicdomain/zero/1.0/) applies to the data made available in this article, unless otherwise stated in a credit line to the data. 